Magyar Honvédség Egészségügyi Központ, Neurológiai Osztály

\title{
Obstruktív alvásfüggő légzészavarok hatása a kognitív és exekutív teljesítményre
}

\section{Dr. habil Szakács Zoltán orvos ezredes, PhD}

Kulcsszavak: alvásfüggö légzészavar, hipoxia, Wisconsin teszt, agyi áramlás vizsgálat, CPAP kezelés

Jelen munkánkban több évtized alvásdiagnosztikai, neuropszichológiai és funkcionális agyi áramlási vizsgálatok egybevetésével nyert tapasztalatait összegezzük.

Fontos eredmény, hogy az obstruktív légzészavarok korán, még normál oxigenizáció mellett is jelentős áramlási deficitet okoznak. Másrészt igazoltuk, hogy a funkcionális áramlási rezervkapacitás beszüküléséért, a hipoxia és nem az alvásfragmentáció, vagy a deszaturáció a felelős. Szintén új eredmény a nappali mentális flexibilitás csökkenése és a rezervkapacitás beszükülése közötti összefüggés igazolása. Hangsúlyozzuk, hogy a konkrét eredmények a megfelelö páciens szelekció, a rutin számára jól értelmezhető neuropszichológiai, és agyi áramlás vizsgálatok együttes alkalmazásának köszönhetö.

Az alvásfüggő légzészavarok jól diagnosztizálhatók, eredményesen kezelhetők. A kezeletlen esetek és a keringési vagy anyagcsere betegségek közötti egyértelmü összefüggések felismerése után, a nappali életminőség megőrzése is fontos kérdéssé vált.

A közelmúlt politikai eseményeit követően a katonai feladatok jellege megváltozott. A megelőzően egymás mellett működő alakulatok tevékenységét felváltotta a többnemzeti kötelékben, otthoni szövetséges bázisok nélkül végrehajtott információs, hálózatközpontú, hatásalapú, legtöbbször aszimmetrikus müvele- tek végrehajtása [1-2]. Ennek kapcsán a müveletben résztvevő katona nem csupán parancsot teljesít, hanem szükség esetén kezdeményező, folyamatosan értékeli helyzetét, döntéseket hoz és mint önálló egység, része az informatikai hálózatnak.

A fenti megváltozott típusú kihívások nem egyeztethetők össze az alvás-ébrenlét zavarok okozta fokozott nappali álmosság tünet együttesével [3-4]. Azonban a keringési betegségekkel, bármennyire is evidens az összefüggés a jó minőségű alvás és a másnapi teljesítmény között, ebben a témakörben ok és okozati összefüggések helyett csak következtetésekről és korlá- 
tozott értékű asszociációkról beszélhetünk. Ennek hátterében döntően három fö probléma, a poliszomnográfiás eredmények nem egységes értelmezése, a nappali teljesítmény körüli definíciós bizonytalanságok és a vizsgált betegcsoportok inhomogenitása áll.

Jelen munkánk több évtized eredményeinek összegzésével próbál rávilágítani a tényre, hogy a fenti ellentmondások lehetőség szerinti kiküszöbölésével és a müszeres vizsgálatok harmonizálásával, megfelelő vizsgálati csoportok kialakításával, szakmailag iránymutató, egyértelmủ eredmények nyerhetők.

\section{Páciensek kiválasztása}

A nemzetközi gyakorlatban elsőként korrekt alcsoportokat képeztünk, szubjektív panaszok, kérdőívek mellett objektív poliszomnográfiás eredményekre támaszkodva.

Elkülönítettük a súlyos hipoxiával járó intermittáló hipoxia reoxigenizáció (IHR) eseteket, a megtartott oxigenizációjú, de szintén súlyos OSAS esetektől (normoxémiás OSAS csoport). További alcsoportokat képezve külön vizsgáltuk a hagyományos és a nem konvencionális izolált alvásfragmentációval járó esetek (régebbi nomenklatúra szerint fokozott felsőlégúti ellenállás (UARS szindróma) eredményeit. Többszöri vizsgálati periódusokban összességében több mint 200 páciens került beválasztásra az egyes protokollokba [5-8].

\section{Neuropszichológiai vizsgálatok}

Saját munkáink során, célzott egyszerüsítést követően, nem lebenyfunkciókat, hanem vigilitásra és fenntartott figyelemre épülő mentális flexibilitást vizsgáltunk.
Vigilitás és fenntartott figyelem vizsgálatát SART (sustained attention to response task) próbával végeztük [9]. A teszt lényege, hogy a számítógép képernyőjén 1-9 közötti számok jelennek meg, véletlenszerüen, eltérő méretben. A vizsgált személynek a szám megjelenésekor minél előbb, gombnyomással kell reagálnia, kivéve, ha a felbukkanó szám 3-as. Egymás után 225 alkalommal jelennek meg a számok, ezen belül a 3-as 25 esetben.

$\mathrm{Az}$ instruálás során egyaránt hangsúlyozzuk a minél rövidebb reagálási idő, illetve a megfelelő reakció fontosságát. Az eredményeket számszerüen értékeljük, ezen belül megkülönböztetünk úgynevezett „no-go hibát”, amikor a 3-as számra való tekintettel nem kellett volna megnyomni a gombot, valamint "go" hibát, amikor a gombnyomás elmaradt. A kettő összege adja a teljes hibaszámot. Az egyes vizsgálatok 4 percig tartanak. A kezdés elött rövidített próbára is lehetőség nyílik.

$\mathrm{Az}$ ismert napszaki teljesítményingadozás miatt a próbát két időpontban, 8.00-9.00 óra, illetve 13-14 óra között is elvégeztük. Tekintettel a hibás válaszadás módosító, lassító hatására, a reakció időket nem, csak a hibás válaszok számát értékeltük. A vizsgálat alkalmazásával, az alvásbetegséghez társuló pszichomotoros tempó és vigilitás zavar mentális flexibilitást módosító hatását kívántuk feltérképezni.

A mentális felxibilitást, a nemzetközileg is standardizált, automatizált Wisconsin kártya szortírozó teszttel (Wisconsin Card Sorting Test Computer Research Edition WCST:CV4 ${ }^{\mathrm{TM}}$ ) végeztük. Ez a 128 kártyából álló hagyományos vizsgálat számítógépes változata. Az eljárás során négy stimuluskártyát és $(2 \times 64)$ válaszkártyát alkalmaztunk. A stimuluskártyák mindegyike eltér egymástól színben, számban 
és formában. A vizsgálati személyeknek a válaszkártyákat a stimuluskártyákhoz kell illeszteniük úgy, hogy a program a válaszadás után visszajelez arról, hogy a válasz jó volt-e vagy sem.

A vizsgálati személy nem tudja, hogy milyen osztályozási elvek alapján kell válaszolnia, és hogy ezek az elvek hogyan változnak. Az osztályozási elveket (szín, forma, szám, szín, forma, szám) akkor változtatja meg a program, ha a páciens 10 kártyát egymás után a megfelelő stimuluskártya alá helyezett el, vagyis megtanult egy kategóriát. A vizsgálat akkor fejeződik be, ha a vizsgálati személy mind a hat kategóriát megtanulta, illetve ha a 128 válaszkártya elfogy. Minden esetben életkorral korrigált $t$ értékeket kaptunk, ahol a nagyobb szám jobb teljesítményt jelent. A normál átlag a 45-54 értéknek felel meg.

A teszt 16 mutatójából külön kiemeltük az alábbi kategóriákat: perszeveratív válaszok t-értéke, perszeveratív hibák t-értéke, nem perszeveratív hibák t-értéke, konceptuális válaszok t-értéke.

\section{Regionális agyi funkcionális vizsgálatok}

Összességében az IHR-OSAS, normoxémiás OSAS és az izolált alvásfragmentációval járó esetek alkotta csoportok résztvevői kerültek a regionális agyi müködés térképezésére szolgáló technetium $99 \mathrm{~m}$-al jelzett hexamethylpropylene amine-oxime (Tc99m-HMPAO rCBF) regionális „single photon emissziós computer tomográfiás" (SPECT) áramlás vizsgálatra.

Egyúttal kiegészítő intravénás Acetazolamide terheléses rezervkapacitás mérés is készült.

A vizsgálatokra kétfejes General Electric Infinia készülékkel, a standard poliszomnográfiás vizsgálat utáni reggelen került sor azonos időpontokban.

A hosszmetszeti követés során, 12 hónappal a megkezdett kezelést követően esedékes kontroll kapcsán a funkcionális vizsgálatokat megismételtük és az esetleges változások felmérésére a kezelés elötti és utáni eredményeket öszszehasonlítottuk. Áttekintve a nemzetközi szakirodalmat, munkánk ezen a ponton úttörő jellegü. Az alvásvizsgálatok során eddig nyert SPECT eredmények vagy epizodikus, önkontroll nélküli vizsgálatok, vagy a számos módszertani hiányosság (betegcsoportok kiválasztása, jelzőanyag minősége, vizuális értékelés hiánya) miatt értékelhetetlenek, illetve nem tartalmaznak egyidejü rezervkapacitás és neuropszichológiai kiegészítést [10-12].

\section{Eredmények}

SART vizsgálat kapcsán az első vizsgálat minden alcsoportban kóros eredményt adott, mind a go, mind a no-go hibák tekintetében. Követéses kontroll kapcsán az esetek 95\%-ban az értékek rendeződtek, sőt egyes esetekben a javulás kapcsán a korrelált normál kontrollnál is jobb eredményeket mutattak.

Wisconsin-kártya teszt eredményei kapcsán a normoxémiával járó esetekben a pozitivitás mértéke $5 \%$ alatt maradt, ezzel szemben az IHR-OSAS alcsoportban $50 \%$ feletti volt a pozitív esetek aránya. A kóros eseteket a perszeveratív hibák dominálták, a nem perszeveratív hibák t-értékének csökkenése nem érte el a szignifikáns szintet. Kontroll során javulás csak 30\%-ban fordult elö, a többi esetben a kóros eredmények változatlanok maradtak.

SPECT vizsgálat az izolált alvásfragmentációval járó esetekben, vagy 
az apnoe normoxémiás alcsoportjaiban azonos számban (90\%-ban pozitív eredményekkel) és mértékben (egy, vagy több lebenyre kiterjedő hipofixációs minta) mutatott eltérést, mint a típusos IHR alcsoportban.

Különbség a lokalizációban volt. A hipoxémiával járó esetekben döntően a frontális lebeny és ezen belül is a szubdomináns oldal volt érintett. Ezzel szemben a normoxémiával járó eseteket temporo parietális érintettség jellemezte, az egyes oldalak azonos bevonásával.

Kontroll SPECT vizsgálat az IHR esetekben csak 40\%-ban mutatott rendeződő állapotot. Ezzel szemben a normoxémiával járó különböző alcsoportokban ez az arány $80 \%$ feletti volt.

A funkcionális rezervkapacitás mérés során pozitivitás csak az IHR alcsoportban, egyidejü jelentős hipoxémia mellett jelentkezett.

Hosszmetszeti képben az eltérés perzisztáló SPECT pozitivitás ellenére is rendeződhetett.

SPECT és neuropszichológiai eredmények egyidejű elemzésekor a vigilitást és pszichomotoros tempót jellemzö, de egyúttal fenntartott figyelmet és válasz gátlást is igénylő SART átlagok minden alcsoportban, a SPECT eltérés lokalizációjától és a kísérő funkcionális rezervkapacitás értéktől függetlenül, kórosan magas értéket adtak, ezen belül a hipoxiás esetek délelőtti „go hiba” átlag értékei voltak a legmagasabbak, jellemzően frontális SPECT eltéréssel kísérve. Ugyanakkor a kontroll mérés kapcsán az eltérő súlyosságú esetek mindegyike szignifikánsan, „prompt” javultak.

Ezzel szemben a mentális flexibilitást vizsgáló Wisconsin próba pozitivitás kizárólag az egyidejüleg igazolt hipoxémia + beszükült rezervkapacitással járó esetekben fordult elő. Kontroll kapcsán, szemben a vigilitás azonnali javulásával, itt ez csak részlegesen és csak a rezervkapacitás egyidejü rendeződése esetén fordult elö.

\section{Összegzés}

Vizsgálataink során munkacsoportunk elsőként igazolta, hogy a poliszomnográfiás eredmények alapján még enyhének tartott normoxémiás esetek heterogén alcsoportjai, a súlyos, intermittáló hipoxia-reoxigenizáció mintával járó alvásfüggő légzészavarokkal azonos gyakorisággal és kiterjedéssel okoznak regionális áramlás eltéréseket, amelyeken belül a normoxémiával járó esetekben a halántéklebeny, a hipoxiával kísért esetekben a homloklebeny eltérések domináltak. Elsőként igazoltuk, hogy a regionális rezervkapacitás beszűkülésének hátterében nem az alvásfragmentáció vagy a deszaturáció, hanem döntően az intermittáló hipoxia áll. Rámutattunk a mentális flexibilitás teszt pozitivitás és a beszűkült rezervkapacitás kapcsolatára. A követéses kontroll eredmények alapján kimutattuk, hogy a vigilitás és figyelem az eredményes kezelés kapcsán javult, illetve rendeződött. Ezzel szemben az exekutív zavart okozó mentális flexibilitást érintő eltérések, a rendeződő áramlási viszonyok ellenére is perzisztálhatnak.

Követéses eredményeink alapján, a kontroll kapcsán észlelt irreverzibilis, magasabb szintü exekutív funkciózavarok aláhúzzák a korai felismerés és az ennek alapját képező szürővizsgálatok fontosságát.

\section{Irodalom}

[1] Szternák Gy:: A NATO új stratégiája és a fegyveres erő feladatai, fejlesztése közötti kapcsolat. Sereg Szemle, 2011, 9 (1): 21-35. 
[2] Koós G., Szternák Gy.: A katonai műveletek megvívásának jellemzői napjainkban és a jövőben. Sereg Szemle, 2012, 10(4): 5-18.

[3] Szakács Z., Köves P.: Screening for the obstuctive sleep apnea syndrome among guards in alternating work shifts. AARMS 2005, 4 (1): 201-9.

[4] Szakács Z., Köves P.: Alvás-ébrenlét zavarok és sajátos vonatkozásai a katonai szolgálat körülményei között. Honvédorvos, 2005, 1 (2): 30-40.

[5] Koves P., Szakacs Z., Bernath I., Molnar M.. Cognitive deficits in obstructive sleep apnea. Sleep, 2001, 24: A287-A287, 494 Suppl. S.

[6] Köves P., Z. Szakács Z., Bernát I., Molnár M.: HMPAO SPECT and neuropsychological examinations in OSAS patients treated with CPAP. J.S.R., 2002, 11S1: 127-128.

[7] Köves P., Szakács Z., Bernát I.: Tc99mHMPAO rCBF SPECT findings in OSAS patients. Sleep, 2003, 26S: 232.

[8] Bernát I, McNamara P., Szakács Z., et al.: Hyperviscosity as a possible cause of positive acoustic evoked potential findings in patients with sleep apnea: A dual electrophysiological and hemorheological study. Sleep Medicine, 2009, 10: 361-67,

DOI: 10.1016/j.sleep.2008.03.012

[9] Van, S.M.K., Thijs, R.D., Fronczek, R. et al.: Sustained attention to response task (SART) shows impaired vigilance in a spectrum of disorders of excessive daytime sleepiness. Journal of Sleep Research, 2012, 21 (4): 390-5, DOI: 10.1111/j.1365-2869.2011.00979.x.

[10] Ficker, J.H., Feistel, H., Moller, C. et al.: Changes in regional CNS perfusion in obstructive sleep apnea syndrome: initial SPECT studies with injected nocturnal 99mTc-HMPAO. Pneumologie, 1997, 51(9): 926-930.

[11] Eun Yeon Joo, Woo Suk Tae, Sun Jung Han, et al.: Reduced Cerebral Blood Flow During Wakefulness In Obstructive Sleep Apnea-Hypopnea Syndrome. Sleep, 2007, 30(11):1515-1520,

DOI: $10.1093 /$ sleep/30.11.1515

[12] Shiota S, Inoue Y, Takekawa H, et al.: Effect of continuous positive airway pressure on regional cerebral blood flow during wakefulness in obstructive sleep apnea. Sleep Breath. 2013,Sept. 13. [Epub ahead of print], DOI: $10.1007 / 311325-013-0887-S$

\section{Col. Z. Szakács MDMC, PhD}

\section{Neuropsychological consequences of different types of sleep related breathing disorders}

In the present work we give an overview of our cumulating results gained in our sleep laboratory while investigating the occurence and the neuropsychological consequences of different types of SRBD with extended imaging of regional cerebral brain functioning, and also estimating cerebral functional reserve capacity by SPECT. To our knowledge, it was a crucial step to demonstrate that both normoxemic and hypoxic cases had the capacity to give rise to regional cerebral blood flow alterations by SPECT. Furthermore, by monitoring autoregulation capacity we have realised, that not fragmented sleep, but hypoxia is responsible for impaired cerebrovascular reserve capacity. Our results have also shed light on the relationship between failure on mental flexibility test and altered reserve capacity. Follow up results underlined that launching effective therapy was associated only in limited number of cases with improvement on mental flexibility test. The issue is of importance, because improving knowledge about the mechanism of regeneration could enhance our ability to rehabilitate military personnels having been previously trained at high-cost.

Keywords: sleep related breathing disorders, hypoxia, Wisconsin test, regional cerebral blood flow investigation, CPAP therapy

Dr. Szakács Zoltán o. ezds. 1134 Budapest, Róbert Károly krt. 44. 